\title{
EFEITOS DA SACAROSE E DO NITROGÊNIO INORGÂNICO SOBRE A MULTIPLICAÇÃO "IN VITRO" DE BROTAÇÕES DE PORTA-ENXERTO DE CITROS $\left({ }^{1}\right)$
}

\author{
EDUARDO OSSAMU NAGAO $\left({ }^{2}\right)$, MOACIR PASQUAL $\left(\left(^{3,4}\right)\right.$ e JOSÉ DARLAN RAMOS $\left({ }^{3}\right)$
}

\begin{abstract}
RESUMO
O presente trabalho objetivou estudar os efeitos da sacarose e do nitrogênio inorgânico $\left(\mathrm{NH}_{4} \mathrm{NO}_{3}\right.$ e $\left.\mathrm{KNO}_{3}\right)$ sobre a multiplicação "in vitro" de Poncirus trifoliata (L.) Raf. Brotos apicais obtidos através de sucessivas repicagens em meio Murashige \& Skoog (MS) acrescido de BAP $1,0 \mathrm{mg} / 1$ e ANA $1,0 \mathrm{mg} / 1$, foram transferidos para novo meio MS suplementado com as combinações de sacarose $(0 ; 7,5 ; 15$; $30 ; 45$ e $60 \mathrm{~g} / \mathrm{l})$ e nitrogênio inorgânico $(0 ; 1 / 4 ; 1 / 2 ; 1$ e $2 \mathrm{MS})$ dos níveis presentes no meio MS. Os brotos foram mantidos a 2.500 Lux por 16 horas diárias, com temperatura de $27 \pm 2^{\circ} \mathrm{C}$. Após 45 dias de cultivo, avaliaram-se o número total de brotos e o número de brotos com medidas superiores a $1 \mathrm{~cm}$ de comprimento. Observou-se que as doses da sacarose e do nitrogênio inorgânico afetaram as características avaliadas, sendo as melhores respostas obtidas quando se utilizaram concentrações entre 30 e $45 \mathrm{~g} / 1$ da sacarose associadas ao dobro da dose (2 MS) do nitrogênio inorgânico presente no meio MS.
\end{abstract}

Termos de indexação: cultura de tecido, Citrus, sacarose, nitrogênio inorgânico.

\section{ABSTRACT \\ EFFECTS OF SUCROSE AND INORGANIC NITROGEN ON MULTIPLICATION OF "IN VITRO" CULTURE OF PONCIRUS TRIFOLIATA}

It was studied the effects of sucrose and inorganic nitrogen on multiplication of $\left(\mathrm{NH}_{4} \mathrm{NO}_{3}\right.$ and $\left.\mathrm{KNO}_{3}\right)$ "in vitro" culture of Poncirus trifoliata (L.) Raf. Apex buddings from successive multiplications in MS medium added with BAP $1.0 \mathrm{mg} / 1$ and ANA $1.0 \mathrm{mg} / \mathrm{l}$ were placed into new MS media where different tested combinations of sucrose $(0 ; 7.5 ; 15 ; 30 ; 45$ and $60 \mathrm{~g} / \mathrm{l})$ and inorganic nitrogen levels (0 MS;

(1) Recebido para publicação em 29 de novembro de 1993 e aceito em 27 de maio de 1994.

${ }^{2}$ ) Instituto de Ciências Biológicas da Fundação Universidade do Amazonas, 69020-390 Manaus (AM).

$\left({ }^{3}\right)$ Escola Superior de Agricultura de Lavras, Caixa Postal 37, 37200-000 Lavras (MG).

$\left({ }^{4}\right)$ Bolsista do CNPq. 
1/4 MS; $1 / 2 \mathrm{MS} ; 1 \mathrm{MS}$ and $2 \mathrm{MS}$ ) present in MS medium were tested. The buddings were maintained under the 2,500 lux for 16 daily hours at $27 \pm 2^{\circ} \mathrm{C}$. After 45 days they were evaluated according characteristics of total number of buds and number of buds higher than $1 \mathrm{~cm}$ long. The sucrose and inorganic nitrogen doses affected the rated characteristcs. The best responses observed were between 30 to $45 \mathrm{~g} / 1$ of sucrose associated with double (2 MS) dose of inorganic nitrogen.

Index terms: tissue culture, Citrus, sucrose, inorganic nitrogen.

\section{INTRODUÇÃO}

A micropropagação em associação com outras técnicas da cultura de tecidos de plantas permite a obtenção, em curto espaço de tempo e em qualquer época do ano, de grande número de plantas com boa qualidade fitossanitária e autenticidade varietal.

No caso dos citros, essa técnica é uma alternativa na propagação de porta-enxertos, principalmente daqueles com características importantes como o Poncirus trifoliata (L.) Raf., que apresenta tolerância a temperaturas baixas (Hearn et al., 1974).

O sucesso da micropropagação depende não só dos fatores inerentes ao tecido vegetal (genéticos e fisiologicos) como, também, das condições térmicas e luminosas em que a cultura é mantida e do meio de cultura apropriado que permite a indução, a multiplicação e o crescimento das brotações adventícias. As exigências nutricionais requeridas para o crescimento de um tecido em condições "in vitro" variam de espécie para espécie, de variedade para variedade e até mesmo dentro da própria planta, o que torna necessária a otimização dos meios de cultura.

Na literatura encontram-se várias formulações de meio de cultura para as mais diversas espécies cultivadas "in vitro". Tais meios geralmente são compostos de uma fonte de carboidrato, macro- e micronutrientes e outras substâncias orgânicas. Normalmente, para o cultivo de citros, utilizam-se o meio M.S. (Murashige \& Skoog, 1962) e/ou o M.T. (Murashige \& Tucker, 1969).

A sacarose tem sido o carboidrato preferencialmente utilizado no meio de cultivo, em vista de certas características, como alta solubilidade e rápida metabolização pela maioria das células vegetais (Thorpe \& Beaudoin-Eagan, 1984).

Não só a fonte de açúcar tem grande influência nos processos de cultivo "in vitro" como sua concentração efetiva. Para muitas espécies, a sacarose é empregada nos meios de cultura em uma concentração entre 2 e $4 \%$. Para os citros, as concentrações ótimas de sacarose podem variar de 2 a $7 \%$ de acordo com os explantes utilizados (Chaturverdi \& Mitra, 1974; Navarro et al., 1985; Pasqual, 1985; Said \& Murashige, 1987).

De acordo com Gamborg (1970), a concentração de sacarose afeta a assimilação de nitrogênio do meio de cultura pelas células, e o efeito da citocinina na divisão celular pode também depender da disponibilidade do açúcar. Meios contendo concentração alta de sacarose e baixa de citocinina favorecem a diferenciação e crescimento de brotações.

O nitrogênio, juntamente com a sacarose, é o principal componente em quantidade no meio de cultura, contribuindo de forma efetiva tanto no metabolismo celular como na regulação do seu potencial osmótico. Grey (1987) observou, em seus estudos, que a taxa de consumo de sacarose presente no meio de cultura estaria relacionada com o nível e com a natureza da fonte de nitrogênio.

O crescimento e a morfogênese de células e tecidos de plantas cultivadas "in vitro" são marcadamente influenciados pela disponibilidade e pela forma na qual o nitrogênio é suplementado no meio de cultivo. De acordo com Dougall (1980), o nitrogênio, além de exercer um papel 
importante no crescimento, pode influenciar na produção de metabólitos secundários em plantas superiores.

O nitrogênio inorgânico é geralmente fornecido no meio de cultura na forma de sais de nitrato e/ou de amônio. Esses íons são de grande importância no controle de um $\mathrm{pH}$ adequado no meio de cultura, pois atuam como agente tamponante, favorecendo a absorção de outros íons presentes nesse meio.

Vários são os relatos evidenciando que não só a quantidade relativa de nitrato ou amônio, mas também sua concentração total, podem ser críticas no processo de morfogênese e no crescimento dos tecidos (Gamborg, 1970; Sakuta, 1987).

Objetivou-se, com o presente trabalho, determinar doses de sacarose e nitrogênio inorgânico que propiciassem alta taxa de multiplicação de P. trifoliata (L.) Raf.

\section{MATERIAL E MÉTODOS}

O presente trabalho foi desenvolvido no Laboratório de Cultura de Tecidos Vegetais do Departamento de Agricultura da Escola Superior de Agricultura de Lavras (ESAL), em Lavras (MG), com o P. trifoliata (L.) Raf., um porta-enxerto bastante utilizado na citricultura.

O meio de cultura utilizado nos ensaios foi o MS (Murashige \& Skoog, 1962), com exceção das concentrações de nitrogênio inorgânico total $\left(\mathrm{KNO}_{3}\right.$ e $\mathrm{NH}_{4} \mathrm{NO}_{3}$ ), suplementado com os seguintes reguladores de crescimento: ácido naftalenoacético (ANA), 1,0 mg/l, e benzilaminopurina (BAP), 1,0 $\mathrm{mg} / \mathrm{l}$, de acordo com Pasqual (1985).

Os explantes, obtidos de material já mantido "in vitro", constituídos de brotações apicais com $1 \mathrm{~cm}$ de comprimento e duas gemas, foram cuidadosamente inoculados nos tubos de ensaio distribuídos nos devidos tratamentos.

Os meios de cultura, com $\mathrm{pH}$ ajustado para 5,7 e após solidificados com $0,7 \%$ de ágar, foram distribuídos em tubos de ensaio $(2,5 \times 15 \mathrm{~cm})$ e esterilizados a $121^{\circ} \mathrm{C}$ durante 15 minutos.
Os ensaios foram realizados em sala de crescimento com temperatura de $\pm 26^{\circ} \mathrm{C}$, fotoperíodo de 16 horas e intensidade luminosa de 2.500 lux. Testaram-se seis concentrações de sacarose e 5 de nitrogênio inorgânico total, num fatorial simples $6 \times 5$, com 5 repetições, cada qual constituída por 10 tubos de ensaio.

As concentrações utilizadas de sacarose em gramas/litro foram as seguintes 0,$0 ; 7,5 ; 15 ; 30$; 45 e 60 . Para maior facilidade de interpretação, as concentrações do nitrogênio inorgânico a testar nos meios de cultura foram obtidas de acordo com diluições ou múltiplos das quantidades existentes no meio básico MS: $0,1 / 4,1 / 2,1$ e 2 .

As avaliações foram realizadas 45 dias após a instalação do experimento, através da contagem do número total de brotos e número de brotos maiores que $1 \mathrm{~cm}$.

\section{RESULTADOS E DISCUSSÃO}

O resumo das análises da variância e regressão para o número total de brotos e de brotos superiores a $1 \mathrm{~cm}$ de comprimento encontram-se no quadro 1. Verifica-se que houve diferença significativa, ao nível de $1 \%$, pelo teste $F$, entre os tratamentos contendo diversos níveis de sacarose e nitrogênio inorgânico, bem como para a interação desses fatores, para ambas as características avaliadas.

Os melhores resultados obtidos tanto para o número total de brotos (Quadro 2) como para o número de brotos superiores a $1,0 \mathrm{~cm}$ de comprimento (Quadro 3), foram com $40 \mathrm{~g} / 1$ de sacarose associada ao dobro (2 MS) da concentração de nitrogênio inorgânico presente no meio MS, com 13,4 e 5,9 novas brotações por explante respectivamente (Figuras 1 e 2 ).

Os resultados desse trabalho mostram a necessidade da sacarose e do nitrogênio inorgânico na indução de brotações e são condizentes com a literatura consultada (Gamborg, 1970; Brown \& Thorpe, 1982).

Segundo Thorpe \& Beaudoin-Eagan (1984), a sacarose também estaria relacionada com 0 
aumento de metabolismo de carboidratos, via pentose fosfato, fornecendo uma produção extra de ATP, NADP e compostos intermediários requeridos para o processo de multiplicação celular. A necessidade de nitrogênio está relacionada com bios-
Síntese de aminoácidos e compostos nitrogenados. A energia gerada pelo metabolismo da sacarose também é utilizada nos processos de absorção de compostos orgânicos estruturais ou metabólicos e de outros íons presentes no meio.

Quadro 1. Resumo da análise da variância e regressão para o número total de brotos (NTB) e número de brotos superiores a $1,0 \mathrm{~cm}$ de comprimento (NBS) de $P$. trifoliata obtidos em culturas com diferentes níveis de sacarose e nitrogênio inorgânico

\begin{tabular}{lccc}
\hline & & Quadrados médios e significância \\
\cline { 3 - 4 } Causas da variação & G.L. & N.T.B. & N.B.S. \\
\hline Sacarose & $(5)$ & $38,08^{* *}$ & $25,83^{* *}$ \\
$\quad$ Linear & 1 & $0,98^{*}$ & $32,22^{* *}$ \\
Quadrática & 1 & $129,19^{*}$ & $85,92^{*}$ \\
Cúbica & 1 & 1,6 & 8,25 \\
Nitrogênio & $(4)$ & $137,36^{* *}$ & $24,26^{* *}$ \\
Linear & 1 & $229,46^{*}$ & $67,69 * *$ \\
Quadrática & 1 & $254,53^{*}$ & $23,59^{*}$ \\
Cúbica & 1 & 59,80 & 6,29 \\
Sac. x Nitro & 26 & $0,97^{* *}$ & $6,64^{* *}$ \\
Resíduo & 120 & 0,06 & 0,03 \\
C.V. (\%) & & 2,93 & 6,28 \\
R $^{2}$ & & 0,99 & 0,95 \\
\hline
\end{tabular}

* Significativo ao nível de $5 \%$.** Significativo ao nível de $1 \%$.

Quadro 2. Médias do número total de brotos por explante de P. trifoliata obtidos "in vitro", em diferentes concentrações de sacarose e nitrogênio

\begin{tabular}{clcccrcr}
\hline & \multicolumn{5}{c}{ Nitrogênio Inorgânico } & Média \\
\cline { 2 - 5 } Sacarose & $0 \mathrm{MS}\left(^{1}\right)$ & $1 / 4 \mathrm{MS}$ & $1 / 2 \mathrm{MS}$ & $1 \mathrm{MS}$ & $2 \mathrm{MS}$ & \\
\hline $\mathrm{g} / 1$ & & & & & \\
0,0 & $5,60 \mathrm{aD}\left(^{2}\right)$ & $8,15 \mathrm{cA}$ & $7,85 \mathrm{dAB}$ & $7,70 \mathrm{eB}$ & $6,30 \mathrm{eC}$ & $7,12 \mathrm{f}$ \\
7,5 & $4,90 \mathrm{bcD}$ & $9,80 \mathrm{bB}$ & $11,10 \mathrm{bA}$ & $11,10 \mathrm{bA}$ & $9,30 \mathrm{dC}$ & $9,24 \mathrm{c}$ \\
15 & $5,30 \mathrm{abD}$ & $11,80 \mathrm{aB}$ & $11,15 \mathrm{bC}$ & $13,50 \mathrm{aA}$ & $10,85 \mathrm{cC}$ & $10,52 \mathrm{a}$ \\
30 & $5,50 \mathrm{aD}$ & $7,85 \mathrm{cdC}$ & $12,50 \mathrm{aA}$ & $11,45 \mathrm{bB}$ & $11,70 \mathrm{bB}$ & $9,80 \mathrm{~b}$ \\
45 & $4,50 \mathrm{cE}$ & $7,80 \mathrm{cdD}$ & $8,40 \mathrm{cC}$ & $10,20 \mathrm{cB}$ & $12,45 \mathrm{aA}$ & $8,67 \mathrm{~d}$ \\
60 & $5,50 \mathrm{aE}$ & $7,50 \mathrm{dD}$ & $8,30 \mathrm{cC}$ & $8,95 \mathrm{~dB}$ & $9,60 \mathrm{dA}$ & $7,97 \mathrm{e}$ \\
Média & $5,21 \mathrm{D}$ & $8,81 \mathrm{C}$ & $9,88 \mathrm{~B}$ & $10,48 \mathrm{~A}$ & $10,03 \mathrm{~B}$ & - \\
\hline
\end{tabular}

( $\left.{ }^{1}\right)$ MS - meio de cultura Murashige \& Skoog (1962). $\left({ }^{2}\right)$ As médias seguidas da mesma letra (maiúscula para nitrogênio e minúscula para sacarose) não diferem entre si pelo teste de Duncan a $1 \%$. 
Quadro 3. Número médio de brotos maiores que $1 \mathrm{~cm}$ de comprimento por explante obtido "in vitro" de $P$. trifoliata em diferentes concentrações de sacarose e nitrogênio

\begin{tabular}{|c|c|c|c|c|c|c|}
\hline \multirow{2}{*}{ Sacarose } & \multicolumn{5}{|c|}{ Nitrogênio Inorgânico } & \multirow{2}{*}{ Média } \\
\hline & 0 MS $\left({ }^{1}\right)$ & $1 / 4 \mathrm{MS}$ & $1 / 2 \mathrm{MS}$ & $1 \mathrm{MS}$ & $2 \mathrm{MS}$ & \\
\hline \multicolumn{7}{|l|}{$\mathrm{g} / 1$} \\
\hline 0,0 & $1,05 \mathrm{Ca} \quad\left({ }^{2}\right)$ & $1,05 \mathrm{Ea}$ & $1,30 \mathrm{Fa}$ & $1,15 \mathrm{Fa}$ & $1,10 \mathrm{Ea}$ & $1,13 E$ \\
\hline 7,5 & $1,10 \mathrm{Ce}$ & $3,20 \mathrm{Bb}$ & $3,55 \mathrm{Ca}$ & $2,45 \mathrm{Dc}$ & $1,40 \mathrm{Dd}$ & $2,39 D$ \\
\hline 15 & $1,15 \mathrm{Ce}$ & $3,90 \mathrm{Ac}$ & $4,30 \mathrm{Ab}$ & $4,60 \mathrm{Ba}$ & $2,80 \mathrm{Cd}$ & $3,35 \mathrm{~B}$ \\
\hline 30 & $1,55 \mathrm{Bd}$ & $2,80 \mathrm{Cc}$ & $3,95 \mathrm{Bb}$ & $6,20 \mathrm{Aa}$ & $6,00 \mathrm{Aa}$ & $4,10 \mathrm{~A}$ \\
\hline 45 & $1,50 \mathrm{Be}$ & $2,25 \mathrm{Dd}$ & $3,00 \mathrm{Dc}$ & $3,35 \mathrm{Cb}$ & $6,00 \mathrm{Aa}$ & $3,22 \mathrm{~B}$ \\
\hline 60 & $2,05 \mathrm{Ac}$ & $2,10 \mathrm{Dc}$ & $2,40 \mathrm{~Eb}$ & $2,55 \mathrm{Db}$ & $4,85 \mathrm{Ba}$ & $2,79 \mathrm{C}$ \\
\hline Média & $1,40 \mathrm{e}$ & $2,55 \mathrm{~d}$ & $3,08 \mathrm{c}$ & $3,38 b$ & $3,69 \mathrm{a}$ & -- \\
\hline
\end{tabular}

( $\left.{ }^{1}\right)$ MS - meio de cultura Murashige \& Skoog (1962). $\left({ }^{2}\right)$ As médias seguidas da mesma letra (minúscula para nitrogênio e maiúscula para sacarose) não diferem entre si pelo teste de Duncan a $1 \%$.
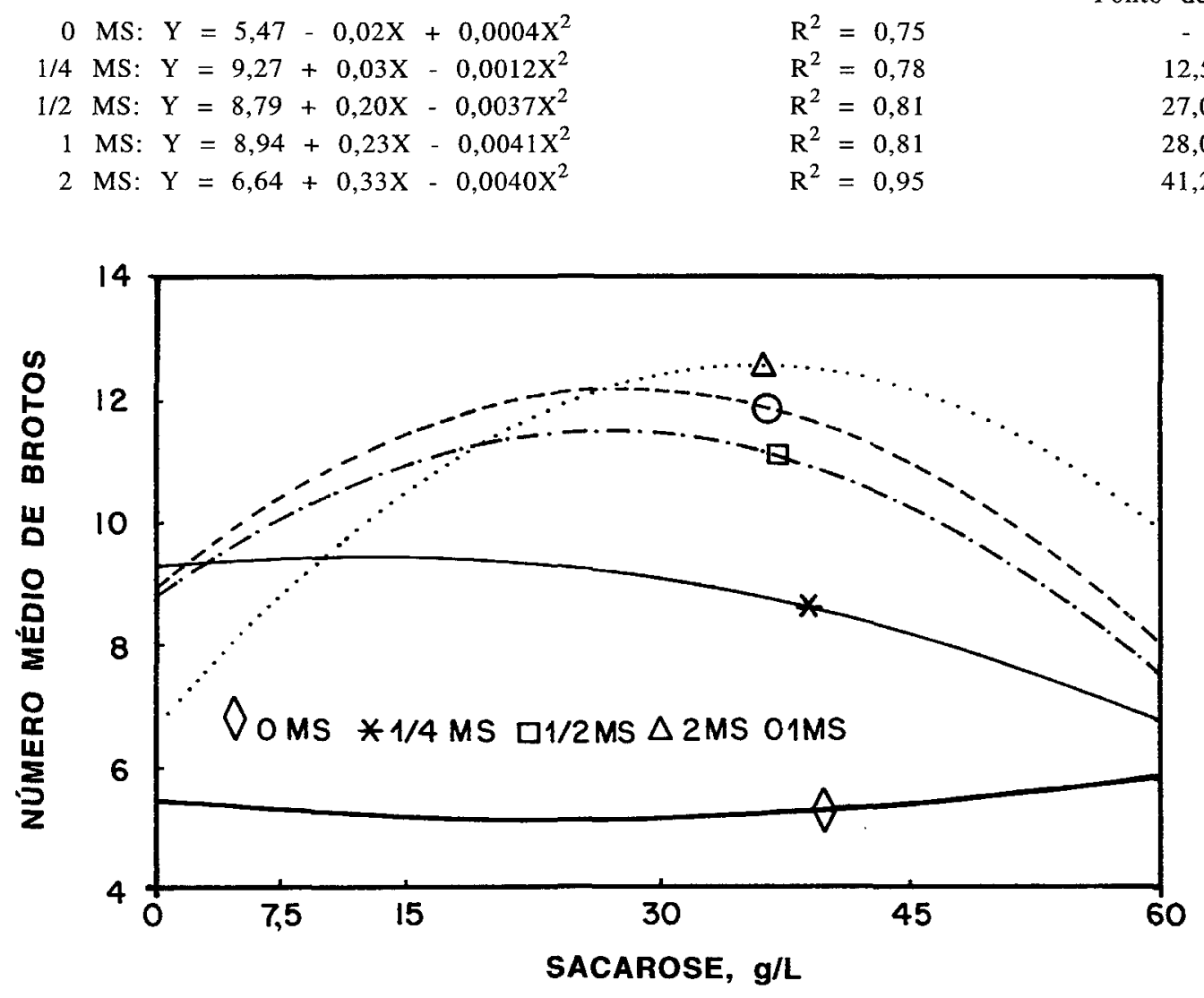

Figura 1. Efeito das combinações de sacarose e nitrogênio no número

Figura 1. Efeito das combinações de sacarose e nitrogên
médio de brotos de $P$. trifoliata "in vitro".
Ponto de máxima

$\mathrm{R}^{2}=0,75$

$\mathrm{R}^{2}=0,78$

12,50

$\mathrm{R}^{2}=0,81 \quad 27,02$

$\mathrm{R}^{2}=0,81 \quad 28,04$

$\mathrm{R}^{2}=0,95$

41,20 


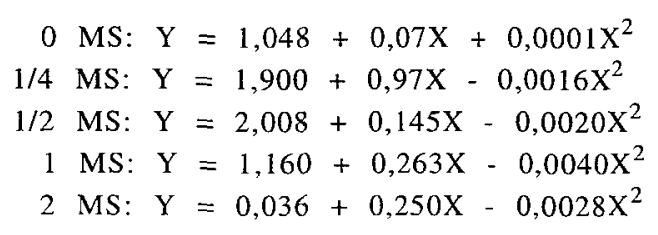

Ponto de máxima

$$
\begin{aligned}
& \mathrm{R}^{2}=0,92 \\
& \mathrm{R}^{2}=0,92 \\
& \mathrm{R}^{2}=0,88 \\
& \mathrm{R}^{2}=0,81 \\
& \mathrm{R}^{2}=0,91
\end{aligned}
$$

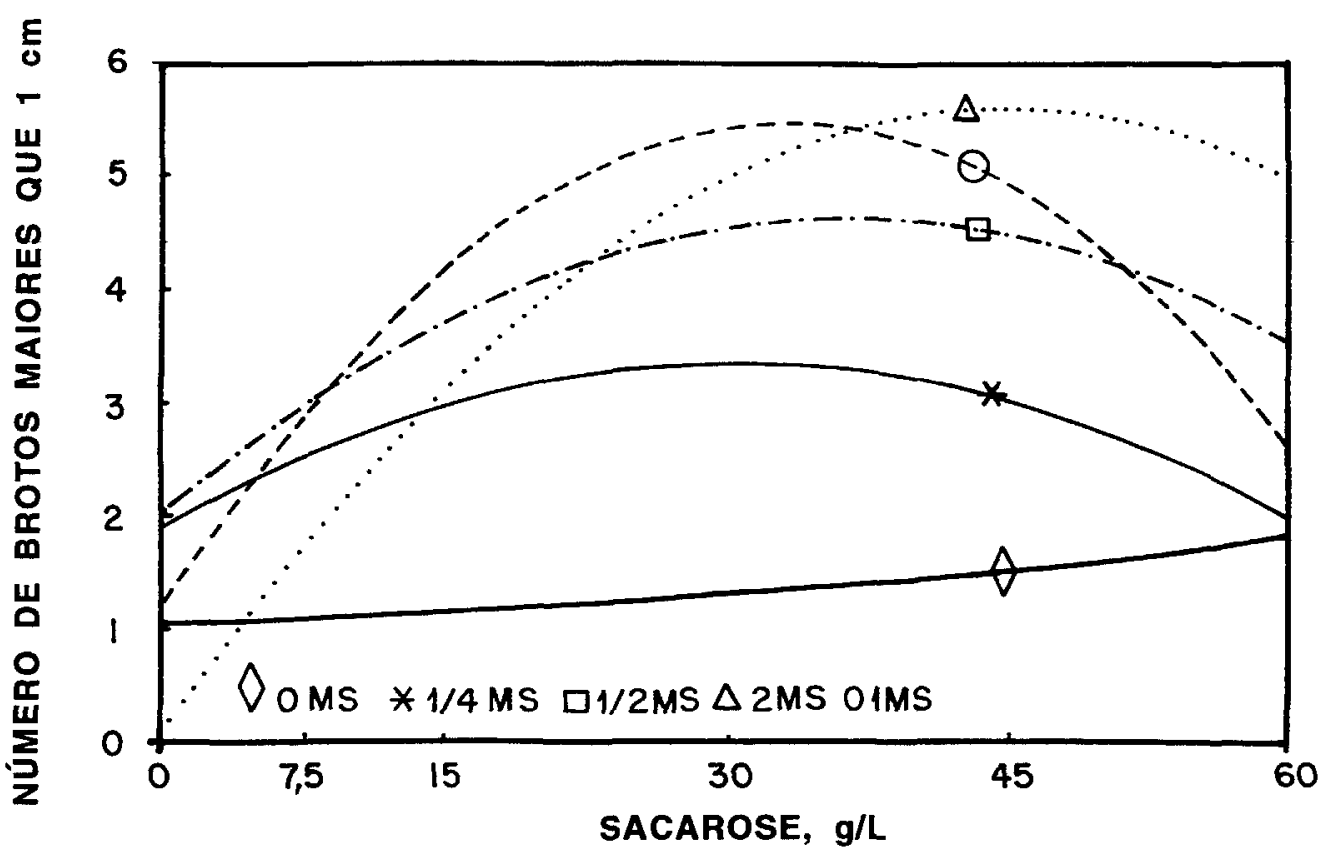

Figura 2. Efeito das combinações de sacarose e nitrogênio sobre o número médio de brotos maiores que $1 \mathrm{~cm}$ de comprimento de $P$. trifoliata "in vitro".

De acordo com Gamborg (1970) os níveis de sacarose e nitrogênio podem atuar na eficiência de alguns reguladores de crescimento, como as citocininas, responsáveis pela promoção de novas brotações. Zenk et al. (1977) observaram que altas concentrações de sacarose induziam a biossíntese de compostos indólicos e conseqüentemente, a síntese de auxinas, as quais, juntamente com as giberelinas, promoveriam o alongamento das brotações, contribuindo para aumentar as novas brotações.

\section{CONCLUSÃo}

As combinações entre a sacarose e o nitrogênio inorgânico foram positivas na multiplicação de brotos, sendo que $40 \mathrm{~g} / \mathrm{l}$ de sacarose, associada ao dobro da dose de nitrogênio inorgânico presente no meio MS (2 MS), proporcionaram os melhores resultados, tanto para o número de novas brotações como para o de brotos superiores a $1 \mathrm{~cm}$.

\section{REFERÊNCIAS BIBLIOGRÁFICAS}

BROWN, D.C.W. \& THORPE, T.A. Mitochondria activity during shoot formation and growth in tobacco callus. Physiologia Plantarum, Copenhagen, 54:125-130, 1982.

CHATURVERDI, H.C. \& MITRA, G.C. Clonal propagation of Citrus from somatic callus culture. Hortscience, Alexandria, 9(2):118-120, 1974.

DOUGALL, D.K. Nutrition and metabolism. In: STABA, E.J., ed. Plant tissue culture as a source of biochemicals. Boca Raton, CRC Press, 1980. p. $51-58$. 
GAMBORG, O.L. The effects of amino acids and ammonium on the growth of plant cells in suspension culture. Plant Physiology, Lancaster, 45:372-375, 1970.

GREY, M. Biochemistry of forest tree especies in culture. In: BONGA, J.M. \& DURZAN, D.J., eds. Cell and tissue culture in forestry. II. Dordrecht, Marthinus Nijhoff, 1987.

HEARN, C.J.; HUTCHINSON, D.J. \& BARRET, H.C. Breeding citrus rootstock. Hortscience, Alexandria, 9:357-358, 1974.

MURASHIGE, T. \& SKOOG, F. A revised medium for rapid growth and biossays with tobacco tissue cultures. Physiologia Plantarum, Copenhagen, 15:473-497, 1962.

MURASHIGE, T. \& TUCKER, D.P.H. Growth factor requeriment of citrus tissue culture. In: CHAP. MAN, H.D. , ed. INTERNATIONAL CITRUS SYMPOSIUM, 1., Riverside, 1969. Proceedings. Riverside, University of California, 1969. p.1155-1161.

NAVARRO, L.; ORTIZ, J.M. \& JUAREZ, J. Aberrant citrus plants obtained by somatic embryogenesis of nucelli cultures "in vitro". HortScience, Alexandria, $20(2): 214-215,1985$.
PASQUAL, M. Regeneração de plantas "in vitro" $e$ radiosensitividade de tecidos nucelares de citros. Piracicaba, 1985. 107p. Tese (Doutorado em Agronomia) - ESALQ-USP, 1985.

SAID, A.G.E. \& MURASHIGE, T. Continuous cultures of tomato and citron roots "in vitro". In vitro, Gaithersburg, 15(8):459-463, 1987.

SAKUTA, M. Effects of sucrose source on betacyanin accumulation and growth in suspension cultures of Phytolacca americana. Physiologia Plantarum, Copenhagen, 71:459-463, 1987.

THORPE, T.A. \& BEAUDOIN-EAGAN, L.D. C-metabolism during growth and shoot formation in tobacco callus cultures. Zeitschrift fuer Pflanzenphysiologie, Stuttgart, 113:337-346, 1984.

ZENK, M.H.; EL-SHAGI, H.; ARENS, H.; STOCKIGTH, J.; WEILER, E.W. \& DEUS, B. Formation of the indole alkaloids serpentine and ajmalicine in culture suspension cultures of Catharanthus roseaus. In: BARZ, W.; REINHARD, E. \& ZENK, M., eds. Plant tissue culture and its biotechnological application. Berlin, Springer Verlag, 1977. p.2743. 